ISSN 1392-3196 / e-ISSN 2335-8947

Zemdirbyste-Agriculture, vol. 104, No. 4 (2017), p. 353-358

DOI 10.13080/z-a.2017.104.045

\title{
The effect of sustainable plant protection and apple tree management on fruit quality and yield
}

\author{
Alma VALIUŠKAITE ${ }^{1}$, Nobertas USELIS ${ }^{1,2}$, Darius KVIKLYS ${ }^{1}$, Juozas LANAUSKAS ${ }^{1}$, \\ Neringa RASIUKEVIČIŪTÉ ${ }^{1}$ \\ ${ }^{1}$ Institute of Horticulture, Lithuanian Research Centre for Agriculture and Forestry \\ Kauno 30, Babtai, Kaunas distr., Lithuania \\ E-mail: a.valiuskaite@1sdi.lt \\ ${ }^{2}$ Institute of Agricultural and Food Science, Aleksandras Stulginskis University \\ Studentų 11, Akademija, Kaunas distr., Lithuania
}

\begin{abstract}
Recently, relatively large amounts of pesticides have been used to control diseases and pests in modern apple production. Our investigations were aimed to estimate the effects of sustainable plant protection system and integrated apple-growing technology on apple fruit quality. The research was carried out in 2011-2013 with apple cultivars 'Auksis', 'Alva', 'Connell Red', 'Ligol', 'Lodel', 'Rubin' and 'Šampion'. Sustainable plant protection system based on the internet supported forecasting system iMETOS ${ }^{\mathrm{s}} \mathrm{sm}$. According to the rules of the sustainable plant protection system, plant protection products with the same active ingredients were used not more than twice, and preharvest interval was 1.5 times longer than indicated on the product label. Plant protection products labelled as "very toxic" and "toxic" were not used. Scab susceptible cultivars "Alva' and 'Ligol' on average were sprayed twelve times when other cultivars - nine times. Sustainable plant protection system did not guarantee total scab control; therefore, damaged fruits should be thinned manually. High-quality fruit yield was on average $39 \mathrm{t} \mathrm{ha}^{-1}$, but the yield of 'Šampion' and 'Ligol' reached $51-56 \mathrm{t} \mathrm{ha}^{-1}$. The $59 \%$ of all investigated cultivars fruits were $70-80 \mathrm{~mm}$ in diameter, and $30 \%$ of fruits - more than $85 \mathrm{~mm}$. All tested cultivars had averaged low index of biennial bearing $0.11-0.34$.
\end{abstract}

Key words: codling moth, crop load management, fruit diameter, iMETOS®sm, scab.

\section{Introduction}

According to EUROSTAT, around 12 million tonnes of apples were produced in European Union (EU) in 2013. The most common orchard plant in EU is an apple tree. Apple tree covers 35\% (450,000 hectares) of the total orchard area (Agriculture, Forestry..., 2015).

Significant amounts of pesticides are used for pest management in orchards all over the world. Chemical control in plant protection has been common since 1950. However, recent evidence suggests that sideeffects of chemical control destroying natural flora and fauna, affecting water, soil and air, causing resistance to diseases and pests, and other factors have occurred since widespread usage of pesticides. Recently, researchers have shown an increased interest in alternatives and complementary techniques and chemical methods. Integrated plant management (IPM) promotes the use all techniques and methods of environmental efficiency of protection strategies in all possible ways (Bound, 2005; Poulsen et al., 2009; Raudonis et al., 2010; Holb et al., 2012; Beckerman et al., 2015; Damos et al., 2015).
The inadequate usage of pesticides has become unacceptable, because it leads to the resistance of pathogen (Poulsen et al., 2009; Damos et al., 2015). According to the EU directive "Sustainable use of pesticides", definition of IPM principles and national guidelines is a topical issue at the moment, since growers are required to implement IPM in their production from the year of 2014 with the aim of reducing the impact and usage of pesticides (Damos et al., 2015). The integrated production or quality assurance schemes operated in many European countries (Poulsen et al., 2009; Holb et al., 2012; Beckerman et al., 2015).

The total production area of crops managed under IPM rules is increasing year by year. However, there were noticed differences between country requirements for soil management, plant nutrition as well as crop protection and control procedures. Among the main problems of the integrated production of fruits the control measures of pests and diseases, a lack of resistant/tolerant cultivars and poor pesticide availability were detected in Lithuania. 
Several investigations on IPM were carried out at the Institute of Horticulture, Lithuanian Research Centre for Agriculture and Forestry. The first investigations of warning equipment Metos D were initiated in 2001-2006 (Raudonis, Valiuškaite, 2003) and from 2007 they were extended using internet-based system iMETOS $®$ sm for prediction of infection risks of apple scab (Raudonis, Valiuškaite, 2009). Scab warning system gave a possibility to optimise the use of fungicides against scab and to reduce spray applications per season. The forecasting models, new tree training systems, and innovative application equipment have been developed to improve treatment coverage, to mitigate pesticide drift and to reduce chemical residues in fruits (Damos et al., 2015).

The sustainable plant protection system protects the environment and gives income to fruit-growers and takes care of farmers and consumers health. The traditional IPM is not so efficient compared to sustainable plant protection system where quantity of pesticides is limited. The aim of the current research was to estimate the effect of sustainable plant protection system and integrated apple-growing technology on apple fruit quality and yield.

\section{Materials and methods}

The experiment was carried out at the Institute of Horticulture, Lithuanian Research Centre for Agriculture and Forestry in 2011-2013. Apple trees of cultivars 'Auksis', 'Alva', 'Connell Red', 'Ligol', 'Lodel', 'Rubin' and 'Šampion' on P 60 rootstock were tested in a full bearing orchard. The orchard was planted in 2002. Planting distance $4 \times 1.25 \mathrm{~m}$. Experimental plots with four apple trees in each were arranged randomly in four replicates. Fruit thinning was performed after natural small and immature fruits drop in June.

The abundance of flowering was assessed at full bloom in $0-5$ score scale, where 0 means that tree does not bloom and 5 - tree blooms abundantly. The yield was recorded for the whole experimental plot and converted to tonnes per hectare.
Alternate bearing index (ABI) was calculated according to Monselise and Goldschmidt (1982):

$$
\mathrm{ABI}=\frac{(\text { year } 1 \text { yield })-(\text { year } 2 \text { yield })}{\text { year } 1+\text { year } 2 \text { yield }},
$$

where $\mathrm{ABI}=0$ is no alternate bearing, and $\mathrm{ABI}=1.0$ is complete alternate bearing.

Average fruit weight $(\mathrm{g})$, diameter $(\mathrm{mm})$ and blush coverage $(\%)$ were determined on random samples of 50 fruits per each experimental plot. Fruits were classified to three diameter classes: $55-69,70-84$ and 85-95 mm. Fruit blush coverage was estimated visually, at least 100 fruits according to a scale: 0 no base colour, 50 - base colour $50 \%$ (= red coloration), $100-$ base colour $100 \%$ (= red coloration).

Sustainable plant protection system based on the internet supported forecasting system iMETOS $\AA$ sm (Pessl Instruments, Austria) was located at the experimental apple orchards. The system iMETOS ${ } \mathrm{sm}$ is equipped with sensors for registration and transmission of data on temperature, relative humidity, rainfall, leaf wetness and other data needed for prediction of apple scab infection. Fungicides were applied on scab sensitive varieties immediately after infection appeared. The same active ingredients of plant protection products were used not more than twice (Table 1), and the preharvest interval was 1.5 times longer than indicated on the label. Plant protection products labelled as "very toxic" and "toxic" were not used.

Fruit scab damage was recorded during the harvest and assessed on random samples of 100 fruits in 0 -2-point scale, where $0=$ no scab symptom, $1=1-2$ spots per fruit and $2=$ more than 3 spots per fruit. Damage incidence was calculated according to the formula $\mathrm{P}=\mathrm{n} /$ $\mathrm{N} \times 100$, where $\mathrm{P}$ is incidence $(\%), \mathrm{n}-$ number of damaged fruits, $\mathrm{N}$ - total number of investigated fruits.

Delta pheromone traps (Biobest, Belgium) were used to monitor codling moth flight activity and population density. Pest population density was expressed as a relative

Table 1. The sustainable pest and disease control system in an apple orchard, average 2011-2013

\begin{tabular}{|c|c|c|c|}
\hline $\begin{array}{l}\text { Growth stage } \\
\text { by } \mathrm{BBCH}\end{array}$ & $\begin{array}{l}12 \text { fungicide treatments, cultivars } \\
\text { 'Alva'/ 'Ligol'/ 'Conell Red' }\end{array}$ & $\begin{array}{l}9 \text { fungicide treatments, cultivars } \\
\text { 'Auksis'/ 'Rubin'/‘Šampion' }\end{array}$ & $\begin{array}{c}7 \text { fungicide treatments, cultivar } \\
\text { 'Lodel' }\end{array}$ \\
\hline 03 & copper hydroxide $(2.5)^{*}$ & - & - \\
\hline $07-09$ & copper hydroxide $(0.75)$ & copper hydroxide $(0.75)^{*}$ & copper hydroxide $(0.75)^{*}$ \\
\hline \multirow{2}{*}{10} & cyprodinil $(0.2)$ & cyprodinil $(0.2)$ & kresoxim methyl (0.2) \\
\hline & thiamethoxam $(0.2)$ & thiamethoxam $(0.2)$ & thiamethoxam $(0.2)$ \\
\hline 57 & captan $(2.0)$ & - & - \\
\hline 59 & cyprodinil $(0.3)$ & cyprodinil $(0.3)$ & cyprodinil $(0.3)$ \\
\hline \multirow{3}{*}{69} & difenoconazole $(0.2)$ & difenoconazole $(0.2)$ & cyprodinil $(0.3)$ \\
\hline & mancozeb (2.0) & mancozeb (2.0) & - \\
\hline & pheromone traps for insects & pheromone traps for insects & pheromone traps for insects \\
\hline \multirow{4}{*}{71} & spirodiclofen $(0.4)$ & spirodiclofen $(0.4)$ & spirodiclofen $(0.4)$ \\
\hline & kresoxim methyl (0.2) & kresoxim methyl (0.2) & kresoxim methyl (0.2) \\
\hline & dithianon $(0.5)$ & dithianon $(0.5)$ & dithianon $(0.5)$ \\
\hline & acetamiprid (0.2) & acetamiprid (0.2) & acetamiprid (0.2) \\
\hline \multirow{2}{*}{73} & difenoconazole $(0.2)$ & difenoconazole $(0.2)$ & \multirow{2}{*}{-} \\
\hline & mancozeb (2.0) & mancozeb (2.0) & \\
\hline \multirow{2}{*}{75} & kresoxim methyl (0.2) & kresoxim methyl (0.2) & \multirow{2}{*}{ deltamethrin $(0.25)$} \\
\hline & deltamethrin $(0.25)$ & deltamethrin $(0.25)$ & \\
\hline 76 & captan $(2.0)$ & captan $(2.0)$ & captan $(2.0)$ \\
\hline 77 & trifoxystrobin $(0.1)$ & - & \\
\hline \multirow{2}{*}{81} & trifoxystrobin $(0.15)$ & trifoxystrobin $(0.15)$ & trifoxystrobin $(0.15)$ \\
\hline & dithianon $(0.5)$ & dithianon $(0.5)$ & dithianon $(0.5)$ \\
\hline
\end{tabular}

Note. ${ }^{*}$ - numbers in brackets represent the rate of product sprayed in $\mathrm{kg}$ or $1 \mathrm{ha}^{-1}$. 
measure based on a mean number of insects captured per trap during a particular time interval (Tamosiunas et al., 2013; Tamošiūnas et al., 2014). Insecticides were applied when the density of pests was reaching the threshold of harmfulness. Apple growth stages were characterised according to the BBCH scale (Meier, 1997).

Statistical analysis. The experimental data were evaluated by general analysis of variance (ANOVA) from the package SELEKCIJA (Tarakanovas, Raudonius, 2003) for randomised block designs. Duncan's multiple range test was used to determine the significant difference between different treatments $(P<0.05)$.

\section{Results and discussion}

Minimising the usage of pesticides in horticulture is an important condition in the sustainable apple production. Lithuanian apple growers participating in the "Agri-environment payments" program shall follow requirements of Council Regulation (EC) No. 1782/32003 (http://data.europa.eu/eli/reg/2003/1782/oj) as well as minimum requirements for fertiliser and plant protection product usage and other relevant, mandatory requirements established by national legislation. Sustainable production depends on good horticulture practices that maintain and improve crop and soil health.

Apple scab was controlled by application of fungicides based on forecasting system iMETOS $® s m$ (Pessl Instruments). This system records meteorological conditions and calculates apple scab infections at three levels: light, medium and high. Scab susceptible cultivars were sprayed when the risk of ascospore release or conidia light infection reached more than $70-80 \%$. Scab susceptible cultivars 'Alva', 'Ligol' and 'Conell Red' were sprayed twelve times when other less susceptible cultivars 'Auksis', 'Rubin' and 'Šampion' - nine times, and 'Lodel' was sprayed seven times per season (Table 1). Cultivar 'Lodel' is resistant to apple scab. However, more fungicide treatments were applied on this cultivar to control the incidence of mildew and fruit rot.

When scab lesions are present on fruits, such production is not marketable. The influence of sustainable plant protection system on fruit quality is provided in Table 2. Reduced pesticide program did not guarantee total scab control; therefore, damaged fruits should be thinned manually. On the average, cultivars 'Ligol', 'Alva' and 'Rubin' had highest amount of damaged fruits (13-19\%) when sustainable plant protection system was efficient for 'Lodel' and 'Auksis' (0-1.7\% of damaged fruits).

Results of our investigation showed that fruits of all cultivars were well protected against diseases and pests. Some studies indicated highly variable damage levels by secondary apple pests like apple sawfly (Tamosiunas et al., 2013; Tamošiūnas et al., 2014; 2015) or green apple aphids (Raudonis et al., 2010) on different apple cultivars in the same orchard, pests were successfully controlled in our experiment by sustainable plant protection system.

Table 2. The effect of the sustainable plant protection system on fruit damage by scab at harvesting (\%)

\begin{tabular}{|c|c|c|c|c|c|c|c|c|c|}
\hline & \multicolumn{3}{|c|}{2011} & \multicolumn{3}{|c|}{2012} & \multicolumn{3}{|c|}{2013} \\
\hline Cultivar & $\begin{array}{l}\text { without } \\
\text { lesions }\end{array}$ & $\begin{array}{c}1-2 \\
\text { lesions } \\
\text { per fruit }\end{array}$ & $\begin{array}{c}\geq 3 \\
\text { lesions } \\
\text { per fruit }\end{array}$ & $\begin{array}{l}\text { without } \\
\text { lesions }\end{array}$ & $\begin{array}{c}1-2 \\
\text { lesions } \\
\text { per fruit }\end{array}$ & $\begin{array}{c}\geq 3 \\
\text { lesions } \\
\text { per fruit }\end{array}$ & $\begin{array}{l}\text { without } \\
\text { lesions }\end{array}$ & $\begin{array}{c}1-2 \\
\text { lesions } \\
\text { per fruit }\end{array}$ & $\begin{array}{c}\geq 3 \\
\text { lesions } \\
\text { per fruit }\end{array}$ \\
\hline Auksis & $100 \mathrm{bc}$ & $0 \mathrm{a}$ & $0 \mathrm{a}$ & $95 \mathrm{~d}$ & $5 \mathrm{e}$ & $0 \mathrm{a}$ & $100 \mathrm{~d}$ & $0 \mathrm{a}$ & $0 \mathrm{a}$ \\
\hline Alva & $87 \mathrm{~d}$ & $10 \mathrm{e}$ & $3 \mathrm{~b}$ & $90 \mathrm{c}$ & $8 \mathrm{~b}$ & $2 \mathrm{~b}$ & $85 \mathrm{e}$ & $13 \mathrm{e}$ & $2 \mathrm{~b}$ \\
\hline Conell Red & $95 \mathrm{e}$ & $4 \mathrm{~d}$ & $1 \mathrm{a}$ & $89 \mathrm{c}$ & $8 \mathrm{~b}$ & $3 \mathrm{~b}$ & $98 \mathrm{~b}$ & $2 b$ & $0 \mathrm{a}$ \\
\hline Ligol & $80 \mathrm{a}$ & $15 \mathrm{c}$ & $5 \mathrm{~d}$ & $81 \mathrm{a}$ & $10 \mathrm{f}$ & $9 \mathrm{c}$ & $83 \mathrm{a}$ & $7 \mathrm{~d}$ & $0 \mathrm{a}$ \\
\hline Lodel & $100 \mathrm{bc}$ & $0 \mathrm{a}$ & $0 \mathrm{a}$ & $100 \mathrm{e}$ & $0 \mathrm{a}$ & $0 \mathrm{a}$ & $100 \mathrm{~d}$ & $0 \mathrm{a}$ & $0 \mathrm{a}$ \\
\hline Rubin & $82 \mathrm{a}$ & $14 \mathrm{c}$ & $4 \mathrm{bcd}$ & $85 \mathrm{~b}$ & $15 \mathrm{~d}$ & $0 \mathrm{a}$ & $96 \mathrm{~b}$ & $4 \mathrm{c}$ & $0 \mathrm{a}$ \\
\hline Šampion & $100 \mathrm{c}$ & $0 \mathrm{a}$ & $0 \mathrm{a}$ & $85 \mathrm{~b}$ & $15 \mathrm{~d}$ & $0 \mathrm{a}$ & $98 \mathrm{~b}$ & $2 b$ & $0 \mathrm{a}$ \\
\hline
\end{tabular}

Note. Values with different letters in the columns are significantly different according to Duncan's test at $P<0.05$.

The activity of apple codling moth adults was determined during all seasons of our investigations (Table 3). The cumulative population density increased until the last week of June and reached its peak on 4 July. Trap catches varied between cultivars during the period of the study. The highest mean trap catches were observed on cultivars 'Lodel' and 'Alva' - 4.67 and 3.27 per codling moths trap ${ }^{-1}$ (Table 3). On the rest of the cultivars numbers of codling moth caught on traps were distributed quite evenly and ranged from 0.87 sawfly trap $^{-1}$ on 'Rubin' to 1.87 on 'Auksis'.

Table 3. Annual mean trap catches ( \pm standard error) of codling moth and fruit $(n=100)$ injury at harvesting

\begin{tabular}{ccc|cc|c}
\hline & \multicolumn{2}{c|}{2011} & \multicolumn{2}{c}{2012} & 2013 \\
\hline Cultivar & $\begin{array}{c}\text { mean catches } \\
\operatorname{trap}^{-1}\end{array}$ & $\begin{array}{c}\text { fruit injury } \\
\%\end{array}$ & $\begin{array}{c}\text { mean catches, } \\
\operatorname{trap}^{-1}\end{array}$ & $\begin{array}{c}\text { fruit injury } \\
\%\end{array}$ & $\begin{array}{c}\text { mean catches, } \\
\text { trap }^{-1}\end{array}$ \\
\hline Auksis & $2.3 \pm 0.8$ & $3.5 \mathrm{bc}$ & $1.4 \pm 0.4$ & $1.0 \mathrm{c}$ & $1.9 \pm 0.6$ \\
Alva & $3.4 \pm 0.3$ & $5.3 \mathrm{ab}$ & $3.1 \pm 0.5$ & $3.3 \mathrm{bc}$ & $3.3 \pm 0.4$ \\
Conell Red & $1.5 \pm 0.1$ & $2.5 \mathrm{bc}$ & $1.2 \pm 0.2$ & $1.3 \mathrm{bc}$ & $1.6 \pm 0.5$ \\
Ligol & $2.0 \pm 0.8$ & $3.5 \mathrm{bc}$ & $1.6 \pm 0.5$ & $2.5 \mathrm{bc}$ & $1.8 \pm 0.6$ \\
Lodel & $5.8 \pm 1.5$ & $8.3 \mathrm{a}$ & $3.5 \pm 0.8$ & $4.5 \mathrm{ab}$ & $4.7 \pm 1.1$ \\
Rubin & $1.0 \pm 0.1$ & $0.5 \mathrm{c}$ & $0.6 \pm 0.2$ & $0.5 \mathrm{c}$ & $1.0 \pm 0.1$ \\
Šmpion & $1.2 \pm 0.5$ & $1.3 \mathrm{c}$ & $0.5 \pm 0.0$ & $0.5 \mathrm{c}$ & $7.0 \mathrm{a}$ \\
\hline
\end{tabular}

Note. Values with different letters in the columns are significantly different according to Duncan's test at $P<0.05$. 
The national requirement of sustainable protection system in the apple orchard is that preharvest interval from the last application of pesticides must be 1.5 times longer than indicated on the product label. This range exceeded from 1.5 to 39.5 days in our trial (Table 4).

An important attribute of apple fruit is its skin colour, which often affects consumer preferences and apple market acceptance. In general, red apples are preferred. Fruit red colour may be the prerequisite of better inner fruit quality (Drogoudi, Pantelidis, 2011; Liaudanskas et al., 2015). In our experiment, optimal mineral fruit tree nutrition, proper pruning and fruit thinning were the main technological means that provide better fruit skin colouring. Cultivars 'Alva', 'Connell Red', 'Rubin' and 'Šampion' had the highest percentage of red fruit skin (Table 4). Apples of 'Ligol' and particularly 'Auksis' were less coloured. Since orchard management was the same for all cultivars, differences were caused by genetic factors.

Table 4. The difference between indicated preharvest interval and interval after the last application in the sustainable protection system, a number of days, average 2011-2013

\begin{tabular}{ccccc}
\hline Cultivar & $\begin{array}{c}\text { Harvesting date } \\
\text { average }\end{array}$ & $\begin{array}{c}\text { Preharvest interval } \\
\text { after last application }\end{array}$ & $\begin{array}{c}\text { Differences } \\
\text { in days }\end{array}$ & $\begin{array}{c}\text { Number of } \\
\text { pesticide applications }\end{array}$ \\
\hline Auksis & $09.05 \pm 2$ & $33(0308) \pm 2$ & +1.5 & 9 \\
Alva & $10.10 \pm 2$ & $55(1608) \pm 2$ & +23.5 & 12 \\
Conell Red & $10.25 \pm 2$ & $71(1608) \pm 2$ & +39.5 & 12 \\
Ligol & $10.15 \pm 2$ & $60(1608) \pm 2$ & +28.5 & 7 \\
Lodel & $10.01 \pm 2$ & $46(1608) \pm 2$ & +14.5 & 9 \\
Rubin & $09.25 \pm 2$ & $41(1608) \pm 2$ & +9.5 & 9 \\
Šmpion & $10.10 \pm 2$ & $55(1608) \pm 2$ & +23.5 & 9 \\
\hline
\end{tabular}

Several studies confirm that the levels of residues of plant protection products detected on apples are highly dependent on the chemistry of the active ingredient, as well as the timing and dose applied (Poulsen et al., 2009). To ensure the highest fruit quality at the end of long storage, apples must be harvested when mature but not when fully ripe. Later harvested fruits were softer and more mature (Kviklienè et al., 2011). The investigated sustainable plant protection system has the requirement for 1.5 times longer preharvest interval than indicated on the product label. The obtained results showed that actual preharvest intervals after the last application exceeded the indicated one from 1.5 to 39.5 days. The results of our study proved that apple scab could be effectively managed with reduced plant protection system and provides a good example for growers enabling a significant reduction of pesticide applications in apple orchards.

Cultivar 'Šampion' gave the highest average yield $-56.3 \mathrm{tha}^{-1}$ (Table 5). The yield of cultivar 'Ligol' was similar - 51.1 t ha' $\mathrm{h}^{-1}$. Cultivars 'Auksis', 'Connell Red' and 'Lodel' gave a rather good yield, but it was significantly lower compared with that of 'Šampion'. The cultivars 'Rubin' and 'Alva' were the least productive, 23.4 and $28.1 \mathrm{t} \mathrm{ha}^{-1}$, respectively.

Stable annual yield is a key factor for successful fruit growing in commercial orchards. Our data demonstrate that technological means of sustainable orchard management allow achievement of this goal. Adequate protection against diseases and pests, optimal mineral fruit tree nutrition, precise dormant and summer pruning and proper fruit thinning created conditions for high annual yields. The alternate bearing index averaged 0.34 for 'Connell Red' and 0.26 for 'Rubin'. Bearing of cultivars 'Šampion' - 0.11, 'Auksis' - 0.14 and 'Lodel' -0.15 was the most stable (Table 5). It is known that 'Auksis' is less bearing cultivar. Alternate bearing index of cultivars 'Alva', 'Ligol', 'Rubin' and 'Connell Red' was not high; thought in other conditions bienniality could be highly expressed (Kviklys et al., 2016).

Applied technological solutions in sustainable orchard management allow producing high-quality fruits. Fruits of cultivar 'Ligol' had the highest weight $-233 \mathrm{~g}$
Table 5. Apple tree productivity as influenced by the sustainable plant protection system, average, 2010-2013

\begin{tabular}{cccc}
\hline Cultivar & $\begin{array}{c}\text { Flowering } \\
\text { abundance } \\
(0-5 \text { score scale })\end{array}$ & $\begin{array}{c}\text { Yield } \\
\mathrm{t} \mathrm{ha}^{-1}\end{array}$ & $\begin{array}{c}\text { Alternate } \\
\text { bearing } \\
\text { index (ABI) }\end{array}$ \\
\hline Auksis & $3.0 \mathrm{a}$ & $40.0 \mathrm{~b}$ & 0.14 \\
Alva & $2.2 \mathrm{a}$ & $28.1 \mathrm{bc}$ & 0.22 \\
Connell & $3.4 \mathrm{a}$ & $36.6 \mathrm{bc}$ & 0.34 \\
Red & $2.8 \mathrm{a}$ & $51.1 \mathrm{ab}$ & 0.25 \\
Ligol & $3.7 \mathrm{a}$ & $37.6 \mathrm{bc}$ & 0.15 \\
Lodel & $3.4 \mathrm{a}$ & $23.4 \mathrm{c}$ & 0.26 \\
Rubin & $3.8 \mathrm{a}$ & $56.3 \mathrm{a}$ & 0.11 \\
Sampion & 3.2 & 39.0 & 0.21 \\
Average & 1.84 & 15.46 & - \\
LSD & 05 & &
\end{tabular}

Note. $\mathrm{ABI}=0$ is no alternate bearing, $\mathrm{ABI}=1.0$ is complete alternate bearing; values with different letters in the columns are significantly different according to Duncan's test at $P<0.05$.

(Table 6). Similar fruit weight was recorded for cultivars 'Connell Red' and 'Rubin'. Cultivars 'Šampion' and 'Alva' produced significantly smaller fruits compared with 'Ligol'. Fruits of cultivars 'Lodel' and 'Auksis' were tiniest - respectively 134 and $145 \mathrm{~g}$.

Genetic, cultural and environmental factors influence fruit size (Bound, 2005). Applied technological solutions in sustainable orchard management allow production of high-quality fruits. Fruit thinning played a significant role in our experiment. Reducing the crop load allows the fruit that remains to become larger (Racskó, 2006; Meland, 2009; Samuolienè et al., 2016). According to Commission Regulation (2004), extra class fruits of large fruited varieties (in our experiment cultivars 'Ligol', 'Rubin' and 'Šampion') should be at least $110 \mathrm{~g}$, other varieties $-90 \mathrm{~g}$. Fruit weight of all tested cultivars fulfilled extra class requirements. Similar tendencies were observed in fruit diameter. Only small part of fruit did not reach 65 or $60 \mathrm{~mm}$ diameter necessary for extra class fruits.

Apple trees of cultivar 'Lodel' produced the highest amount of the smallest fruits measured by the diameter (Table 6). The small fruit size is typical of 
Table 6. Fruit quality as influenced by the sustainable plant protection system, average 2011-2013

\begin{tabular}{|c|c|c|c|c|c|}
\hline \multirow{2}{*}{ Cultivar } & \multirow{2}{*}{$\begin{array}{c}\text { Weight } \\
\text { g }\end{array}$} & \multicolumn{3}{|c|}{ Diameter mm } & \multirow{2}{*}{$\begin{array}{c}\text { Blush coverage } \\
\%\end{array}$} \\
\hline & & $55-69$ & $70-84$ & $85-95$ & \\
\hline Auksis & $145 \mathrm{c}$ & $8.8 \mathrm{~b}$ & $77.6 \mathrm{a}$ & $13.6 \mathrm{c}$ & $40.0 \mathrm{~d}$ \\
\hline Alva & $175 \mathrm{bc}$ & $5.2 \mathrm{~b}$ & $69.3 \mathrm{ab}$ & $25.5 \mathrm{bc}$ & $82.3 \mathrm{a}$ \\
\hline Connell Red & $232 \mathrm{a}$ & $0.7 \mathrm{~b}$ & $29.3 \mathrm{c}$ & $70.0 \mathrm{a}$ & $76.2 \mathrm{ab}$ \\
\hline Ligol & $233 \mathrm{a}$ & $0.6 \mathrm{~b}$ & $49.6 \mathrm{bc}$ & $49.8 \mathrm{ab}$ & $60.8 \mathrm{c}$ \\
\hline Lodel & $134 \mathrm{c}$ & $27.3 \mathrm{a}$ & $68.4 \mathrm{ab}$ & $4.3 \mathrm{~d}$ & $71.6 \mathrm{~b}$ \\
\hline Rubin & $222 \mathrm{ab}$ & $2.2 \mathrm{~b}$ & $53.0 \mathrm{~b}$ & $44.8 \mathrm{~b}$ & $81.5 \mathrm{ab}$ \\
\hline Šampion & $182 \mathrm{~b}$ & $9.9 \mathrm{~b}$ & $66.6 \mathrm{ab}$ & $23.5 \mathrm{bc}$ & $81.1 \mathrm{ab}$ \\
\hline Average & 189 & 7.8 & 59.1 & 33.1 & 70.5 \\
\hline $\mathrm{LSD}_{05}$ & 26.27 & 11.38 & 23.08 & 24.94 & 10.02 \\
\hline
\end{tabular}

Note. Values with different letters in the columns are significantly different according to Duncan's test at $P<0.05$.

'Lodel' (Szklarz, 2004). Cultivars 'Auksis', 'Alva', 'Lodel' and 'Šampion' had the highest percentage of fruits from 70-84 mm group. The biggest apples were of 'Connell Red' and 'Ligol'.

In order to reduce fungicide input without any significant yield loss, the control of apple scab should be based on registration of climatic data, scouting of biotic parameters, infection risks and simulation disease models, resistance management for modern fungicides, efficient available packet of plant protection products, and risk profile of available products.

Adequate and reasonable protection against diseases and pests, optimal mineral fruit tree nutrition, precise dormant and summer pruning and proper fruit thinning were the basis of "Environmentally friendly fruit and vegetable growing system" implemented by the Ministry of Agriculture of the Republic of Lithuania.

\section{Conclusions}

1. In the sustainable plant protection and growth management, the average yield of all tested apple cultivars reached $39 \mathrm{t} \mathrm{ha}^{-1}$. The highest average yield was obtained of cultivars 'Šampion' $\left(56.3 \mathrm{t} \mathrm{ha}^{-1}\right)$ and 'Ligol' (51.1 $\left.\mathrm{t} \mathrm{ha}^{-1}\right)$. The lowest average yield was of 'Rubin' (23.4 t ha-1) and 'Alva' (28.1 t ha' $\mathrm{t}^{-1}$.

2 . The used integrated growing measures influenced the value of low degree alternate bearing index from 0.11 ('Connell Red') to 0.34 ('Šampion'). The average alternate bearing index was 0.21 .

3. Apple fruits were intensively blush coloured from $40.0 \%$ to $82.3 \%$ due to a complex of used measures and cultivar-specific features. Fruit weight of all the tested cultivars fulfilled extra class requirements.

4. The higher apple fruit quality was achieved by the sustainable plant protection system with the limited use of active ingredients together with agrotechnical handling.

\section{Acknowledgments}

This work was carried out within the framework of the long-term research programs "Horticulture: agro-biological basics and technologies" and "Harmful organisms in agro and forest ecosystems" implemented by Lithuanian Research Centre for Agriculture and Forestry.

Received 21042017

Accepted 29082017

\section{References}

1. Agriculture, Forestry and Fishery Statistics. 2015. EUROSTAT statistical book. <http://ec.europa.eu/eurostat/ documents/3217494/6639628/KS-FK-14-001-EN-N. pdf $/ 8 d 6 e 9 d b e-d e 89-49 f 5-8182-f 340 a 320 c 4 b d>$ [accessed 1904 2017].

2. Beckerman J. L., Sundin G. W., Rosenberger D. A. 2015. Do some IPM concepts contribute to the development of fungicide resistance? Lessons learned from the apple scab pathosystem in the United States. Pest Management Science. 71: 331-342.

https://doi.org/10.1002/ps.3715

3. Bound S. A. 2005. The impact of selected orchard management practices on apple (Malus domestica L.) fruit quality: doctoral dissertation. University of Tasmania, Australia, $190 \mathrm{p}$.

4. Commission Regulation (EC) No. 85/2004 of 15 January 2004 on marketing standards for apples. Official Journal of the European Union, 13: 3-18.

5. Damos P., Colomar L. A., Ioriatti C. 2015. Integrated fruit production and pest management in Europe: the apple case study and how far are from the original concept? Insects, 6(3): 626-657.

https://doi.org/10.3390/insects6030626

6. Drogoudi P., Pantelidis G. 2011. Effects of position on canopy and harvest time on fruit physico-chemical and antioxidant properties in different apple cultivars. Scientia Horticulturae, 129 (4): 752-760 https://doi.org/10.1016/j.scienta.2011.05.036

7. Holb I. J., Dremák P., Bitskey K., Gonda I. 2012. Yield response, pest damage and fruit quality parameters of scabresistance and scab-susceptible apple cultivars in integrated and organic production systems. Scientia Horticulturae, 145: $109-117$. https://doi.org/10.1016/j.scienta.2012.08.003

8. Kviklienè N., Kviklys D., Valiuškaitè A., Viskelis P., Uselis N., Lanauskas J., Buskiene L. 2011. Effect of harvest date on fruit maturity, quality and storability of 'Lodel' apples. Journal of Food, Agriculture and Environment, 9 (3-4): 210-213.

9. Kviklys D., Čeidaite A., Lanauskas J., Uselis N., Samuolienè G. 2016. The effect of rootstock on apple tree bearing stability in a cooler climate. Agricultural and Food Science, 25 (1): 81-88.

10. Liaudanskas M., Viškelis P., Kviklys D., Raudonis R., Janulis V. 2015. A comparative study of phenolic content in apple fruits. International Journal of Food Properties, 18 (5): 945-953. https://doi.org/10.1080/10942912.2014.911311

11. Meier U. 1997. Growth stages of mono - and dicotyledonous plants. BBCH monograph, Berlin, Gemany, $622 \mathrm{p}$.

12. Meland M. 2009. Effects of different crop loads and thinning times on yield, fruit quality, and return bloom in Malus $\times$ domestica Borkh. 'Elstar'. Journal of Horticultural Science and Biotechnology. 84 (6): 117-121. https://doi.org/10.1080/14620316.2009.11512607

13. Monselise S. P., Goldschmidt E. E. 1982. Alternate bearing in fruit trees. Horticultural Reviews, 4: 128-173. 
14. Poulsen M. E., Naef A., Gasser S., Christen D., Rasmussen P. H. 2009. Influence of different disease control pesticide strategies on multiple pesticide residue levels in apple. Journal of Horticultural Science and Biotechnology, 84 (6): 58-61. https://doi.org/10.1080/14620316.2009.11512596

15. Racskó J. 2006. Crop load, fruit thinning and their effects on fruit quality of apple (Malus domestica Borkh.). Journal of Agricultural Sciences, 24: 29-35.

16. Raudonis L., Valiuškaitè A. 2003. Research on pest and disease control in horticultural plants and its development in Lithuania. Sodininkyste ir daržininkystè, 22 (3): 3-14 (in Lithuanian)

17. Raudonis L., Valiuškaite A. 2009. Integrated approach of apple scab management using iMETOS warning system. Sodininkystè ir daržininkystè, 28 (3): 181-191.

18. Raudonis L., Duchovskienè L., Valiuškaitė A., Survilienė E. 2010. Toxicity of biopesticides to green apple aphid, predatory insects and mite in an apple-tree orchard. Zemdirbyste-Agriculture, 97 (1): 49-54.

19. Samuolienè G., Čeidaitè A., Sirtautas R., Duchovskis P., Kviklys D. 2016. Effect of crop load on phytohormones, sugars, and biennial bearing in apple trees. Biologia Plantarum. 60 (2): 394-400.

https://doi.org/10.1007/s10535-015-0581-3
20. Szklarz M. 2004. Evaluation of apple cultivars with different susceptibility to scab (Venturia inaequalis Aderh.). Journal of Fruit and Ornamental Plant Research, 12: 89-95.

21. Tamosiunas R., Duchovskiene L., Valiuskaite A. 2013. Monitoring of sawfly populations (Hymenoptera: Symphyta: Hoplocampa spp.) in plum and apple orchards using visual traps. Proceedings of Latvian Academy of Sciences, section B: Natural. Exact and Annlied Sciences. 67 (2): 130-135. https://doi.org/10.2478/prolas-2013-0020

22. Tamošiūnas R., Valiuškaitè A., Survilienè E., Duchovskienè L., Rasiukevičiūtė N. 2014. Variety-specific population density and infestation levels of apple sawfly (Hoplocampa testudinea Klug) in two differently managed apple orchards in Lithuania. Zemdirbyste-Agriculture, 101 (2): 205-214. https://doi.org/10.13080/z-a.2014.101.027

23. Tamošiūnas R., Valiuškaitè A., Jukna L., Tamošiūnas K., Žiogas A. F. 2015. Spatial distribution patterns of apple sawfly populations in two differently managed commercial annle orchards. Zemdirbvste-Agriculture, 102 (1): 73-80. https://doi.org/10.13080/z-a.2015.102.009

24. Tarakanovas P., Raudonius S. 2003. Agronominiu tyrimų duomenų statistinė analizè taikant kompiuterines programas ANOVA, STAT, SPLIT-PLOT iš paketo SELEKCIJA ir IRRISTAT. Lithuanian University of Agriculture, $58 \mathrm{p}$. (in Lithuanian).

ISSN 1392-3196 / e-ISSN 2335-8947

Zemdirbyste-Agriculture, vol. 104, No. 4 (2017), p. 353-358

DOI $10.13080 / \mathrm{z}-\mathrm{a} .2017 .104 .045$

\title{
Aplinką tausojančios augalų apsaugos sistemos ir obelų auginimo technologijos taikymo įtaka vaisių kokybei bei derliui
}

 \\ ${ }^{1}$ Lietuvos agrarinių ir miškų mokslų centro Sodininkystès ir daržininkystès institutas \\ ${ }^{2}$ Aleksandro Stulginskio universiteto Žemès ūkio ir maisto mokslų institutas
}

\section{Santrauka}

Pastaruoju metu sodininkystèje ligoms ir kenkejjams kontroliuoti sunaudojami dideli kiekiai pesticidų. Tyrimo tikslas - ịvertinti aplinką tausojančios augalų apsaugos sistemos ir integruotos obelų auginimo bei priežiūros technologijos įtaką obuolių vaisių kokybei. Tyrimai atlikti 2011-2013 m. su veislių 'Auksis', 'Alva', 'Connell Red', 'Ligol', 'Lodel', 'Rubin' ir 'Šampion' obelimis. Aplinką tausojanti augalų apsaugos sistema yra paremta iMETOS ${ }^{\circledR}$ sm ligų prognozavimo modeliais, susietais su internetine duomenų baze. Atsižvelgiant ị aplinką tausojančios augalų apsaugos sistemos reikalavimus, ta pati veiklioji medžiaga turi būti naudojama ne dažniau kaip du kartus per vegetacijos laikotarpị ir taikomas 1,5 karto ilgesnis pesticidų karencijos laikotarpis. Labai nuodingi („labai toksiškas“) ir nuodingi („toksiškas“) augalų apsaugos produktai nebuvo naudoti. Obelų rauplèms jautrių veislių 'Alva' ir 'Ligol' obelys buvo apdorotos vidutiniškai dvylika kartų, kitos - devynis kartus. Aplinką tausojanti augalų apsaugos sistema neužtikrino visiškos obelų rauplių kontrolès, todèl pažeisti vaisiai buvo retinami rankiniu būdu. Aukštos kokybès obuolių vidutinis derlius siekė 39 t ha $^{-1}$, o veislių ‘Šampion' ir 'Ligol' jis buvo net 51-56 t ha ${ }^{-1}$. Vidutiniškai 59 \% vaisių buvo 70-80 mm skersmens, o $30 \%$ vaisių skersmuo buvo didesnis nei $85 \mathrm{~mm}$. Visų tirtų veislių obelų pramečiavimo indeksas buvo mažas ir siekè $0,11-0,34$.

Reikšminiai žodžiai: iMETOS®sm, obuolinis pjūklelis, rauplès, vaisių skersmuo, vaisių krūvio reguliavimas. 